\title{
Problem Solving, Social Interest and Love Styles in Romantic Relationships*
}

\author{
Funda Küçük Helvacı ${ }^{1} \quad$ Melek Demir $^{2}$
}

\begin{abstract}
The purpose of this study is to examine the relationship between love attitudes to problem solving and social interest. For this aim, the scales were administered to 330 university students in Turkey. Findings showed that physical abuse was negatively associated with game playing love. Physical abuse was negatively correlated with passionate love. Physical abuse was not found to be significant associated with possessive love, altruistic love, pragmatic love and friendship love. Emotional abuse was positively associated with game playing love. Expectedly, emotional abuse was negatively associated with altruistic love, friendship love and passionate love styles. Functional problem solving was positively correlated with altruistic love, friendship love and passionate love styles. Functional problem solving was negatively correlated with game playing love. But functional problem solving was not found to be significant associated with possessive love and pragmatic love. Social interest was found to be positively linked with altruistic love, friendship love and passionate love styles. Social interest was negatively associated with game playing love. Social interest was not found to be significant correlated with possessive love and pragmatic love styles.
\end{abstract}

Keywords: Love Attitudes, Social Interest, Physical Abuse, Emotional Abuse, Problem Solving

\section{Introduction}

Romantic relationships constitute an irreplaceable aspect of individuals. These relationships have the most meaning and the most special one among the close relationships. The romantic relationships that are established in the adolescence period in which the socialization and social interaction improves are individual's self-expression places. In a relationship that was established in such context develops the communication skills of an individual. This process is a period when individual enter another's world, try to understand and negotiate with him/her. It is highly important for adolescent to establish healthy relationships and attain healthy behavior patterns.

Romantic relationships in the adolescence period have an important role in the quality of romantic relationships in adulthood (Shulman \& Scharf, 2000). Dysfunction in romantic relationships causes physical (Jaremka, Kane, Sunami, Lebed \& Austin, 2020) and psychological health problems (Kansky \& Allen, 2018). Romantic relationships experienced in university years that include the late adolescence period in which the transition to young adulthood occurred by taking place of serious cognitive, social and emotional changes are very important for the development of individuals (Sar1, 2008). One of the most important reasons of university students' apply to university's psychological consulting centers is the difficulties in the romantic relationships (Creasey et al., 1999). Problems are inevitable in the romantic relationships. Couples learn the behaviors of problem solving as well as problems. However, researches and statistics show that couples use negative experiences such as violence, abuse and pressure as a method of problem solving (Kalkan \& Ersanl1, 2008).

Psychological disorders such as decrease in the sense of self and stress, depression and anxiety occurs as a result of emotional abuse that was taken place in adolescence period (Alantar, 1989). The abuse experienced in adolescence period causes certain problems like personal, social and general inconsistency (Tosuntaş-Karakuş, 2006; Yalçın,

\footnotetext{
* This study was produced from first author's Master Thesis, under supervision of second author.

${ }^{1}$ Uzm. Psk. Dan., Şehit Ferhat Ünelli Bilim ve Sanat Merkezi, Turkey, fundakucuk16@gmail.com, ORCID: 0000-00031760-1243

2 Prof. Dr., Ondokuz Mayıs University, Turkey, mkalkan@omu.edu.tr, ORCID: 0000-0002-1280-5952
} 
2007), academic failure (Azizoğlu, 2009), and decrease in the level of self-acceptance (Aydın \& İşmen, 1996). Nevertheless, if the romantic relationships, which make it easier for adolescents to become a part of a group, develops the skills of intimacy, sharing, understanding and self-disclosure (Feiring, 1996), do not include violence and abuse, this will help the occurrence of positive effects of those relationships on individuals.

Solving the problems by staying away from violence and abuse is possible with "Social Interest", according to Adler. Adler argues that emotion of love exists in each person; the proportion of it varies from person to person. According to Adler, "Social Interest" is key feature of each person and it plays a part in every action of people. Social interest includes feeling social to all people and the essence of social interest is caring something else than from himself/herself: it is not egocentrism and arrogance (Leak \& Leak, 2006). Social interest is the feeling of belonging to the society and to the whole human species. On the other hand, it can be expressed as a willingness and behavior to contribute to all people (Huo, 2019). Researchers who support Adler's theory revealed that people who have higher social interest level have common personality traits like friendship, empathy, collaboration, toleration and spirituality etc. (Bubenzer et al., 1991; Crandall, 1991; Leak et al., 1985; Watkins, 1994). Social interest, which includes taking care of others and collaborating with others, is important for mental health (Fung \& Webster, 2018).

Adler believes that social interest reveals itself in friendship, love and study in life duty, and it is necessary in dealing with the big problems life and psychological health brings (Leak \& Leak, 2006). Social interest leads to understanding, caring, and focusing on the well-being of others (Evii, 2020). Therefore, it can be thought that individuals with high social interest will stay away from violence and abuse in their relationship, and will use positive problem solving ways.

Adler states that mature love is a feature of individuals with high social interest (Leak \& Gardner, 1990). Love is one of the life duties of individual, and there should be absolute collaboration (Adler, 1998). Even though people tend to have a consistent style of love, they may experience different styles of love in relationships with different partners (Armstrong, 2021). Individuals with high social interest try to enrich their partners with a real courage (Leak \& Gardner, 1990). In this context, social interest is been associated with romantic relationships and marital well-being (Rennebohm et al., 2017).

When it is examined from this context, revealing the problem-solving behaviors of adolescents in romantic relationships, and the relationship between the social interest level and their love style is thought to be important in terms of preventive-protective interventions to adolescents. For this purpose, the answer to the question "is there any relationship between problem-solving in romantic relationships, social interest and love styles?" is being searched. And in this study, the answer to the question "Is the social interest a meaningful predictor for love styles?" is searched.

\section{Method}

\section{Participants}

This study was conducted with 330 participants consisting of 116 male and 214 female undergraduate students who were taking courses from Ondokuz Mayıs University. The participants with a mean age of 18.94 years $(\mathrm{SD}=.82)$.

\section{Instruments}

\section{Love Attitudes Scale (LAS)}

The scale (Hendrick \& Hendrick, 1986) contains 42 Likert-type items. The scale was adapted to Turkish by Büyükşahin and Hovardaoğlu (2004). It has six dimensions, namely passionate love, game-playing love, friendship love, pragmatic love, possessive love, and altruistic love. Sum scores for each subscale are measured separately. Cronbach alpha values ranged from .51 to .80 for scale (Büyükşahin \& Hovardaoğlu, 2004). The Cronbach alpha values ranged from .55 to .79 for this research. 


\section{Adlerian Social Interest Scale-Romantic Relationships (ASIS-RR)}

The scale was developed by Kalkan to measure social interest on romantic relationships. The ASIS-RR scale contains 24 Likert-type items (Kalkan, 2009). The higher scores on the ASIS-RR indicated a higher level of social interest on romantic relationships. The Cronbach alpha reliability coefficient calculated for the scale was found as .90 and test-retest coefficient of .93 (Kalkan, 2009). The Cronbach alpha value calculated for this research is .90.

\section{Problem Solving on Romantic Relationships Scale for Adolescents}

The scale was developed by Kalkan (2008) to measure adolescents' problem solving behaviors in romantic relationships. The scale contains 38 items. Construct validity was used to test the validity of scale. According to results of the factor analysis, three factors accounted for $37.93 \%$ of the total variance and their Eigen value was over $26.19 \%$. The Cronbach alpha reliability coefficient calculated for the whole scale was found as .91 (Kalkan, 2008). The Cronbach alpha value calculated for this research is .89 .

\section{Data Collection and Analysis}

The scales were applied to the university students in the classroom. The data were analyzed with Pearson correlation and simple linear regression. Pearson Correlation to test whether there is a statistically significant linear relationship is used. Simple linear regression analysis is used the dependent and the independent variables are normally distributed and measured as scores in interval scale (Büyüköztürk, 2006). Since this study was conducted before 2020, there is no ethics committee approval.

\section{Findings}

Are there significant relationships between social interest, problem solving and love styles on romantic relationships?

Bivariate correlation coefficients indicated significant associations between the study variables (Table 1).

\section{Table 1}

Problem Solving, Social Interest and Love Styles on Romantic Relationships

\begin{tabular}{lllllll}
\hline & $\begin{array}{l}\text { Possessive } \\
\text { Love }\end{array}$ & $\begin{array}{l}\text { Game } \\
\text { Playing } \\
\text { Love }\end{array}$ & $\begin{array}{l}\text { Altruistic } \\
\text { Love }\end{array}$ & $\begin{array}{l}\text { Pragmatic } \\
\text { Love }\end{array}$ & $\begin{array}{l}\text { Friendship } \\
\text { Love }\end{array}$ & $\begin{array}{l}\text { Passionate } \\
\text { Love }\end{array}$ \\
\hline Physical Abuse & .03 & $.11^{*}$ & -.04 & -.04 & .02 & $-.13^{*}$ \\
Emotional Abuse & .10 & $.17 * *$ & $-.18^{* *}$ & .01 & $-.12^{*}$ & $-.32^{* *}$ \\
Functional Problem Solving & .03 & $-.13^{*}$ & $.27 * *$ & -.02 & $.16^{* *}$ & $.35^{* *}$ \\
Social Interest & .05 & $-.22^{* *}$ & $.29 * *$ & -.05 & $.18^{* *}$ & $.41^{* *}$ \\
\hline$* p<.05$ & $* * p<.01$ & & & & &
\end{tabular}

As presented in Table 1, Pearson correlation coefficients yielded that physical abuse was negatively associated with game playing love. Physical abuse was negatively correlated with passionate love. Physical abuse was not found to be significant associated with possessive love, altruistic love, pragmatic love and friendship love. Emotional abuse was positively associated with game playing love. Expectedly, emotional abuse was negatively associated with altruistic love, friendship love and passionate love styles.

Functional problem solving was positively correlated with altruistic love, friendship love and passionate love styles. Functional problem solving was negatively correlated with game playing love. But functional problem solving was not found to be significant associated with possessive love and pragmatic love. 
Social interest was found to be positively linked with altruistic love, friendship love and passionate love styles. Social interest was negatively associated with game playing love. Social interest was not found to be significant correlated with possessive love and pragmatic love styles.

Is the social interest a meaningful predictor for love styles?

Simple linear regression analysis was applied to examine the amount of variance in love styles scores which could be accounted for by social interest. The results are shown in Table 2 .

Table 2

Results of Social Interest Scores Predicting Love Styles

\begin{tabular}{llllll}
\hline Variables & $\beta$ & $t$ & $p$ & $R$ & $R^{2}$ \\
\hline Possessive Love & .05 & .97 & .33 & .05 & .003 \\
Game Playing Love & -.22 & -4.10 & .000 & .22 & .05 \\
Altruistic Love & .30 & 5.63 & .000 & .30 & .09 \\
Pragmatic Love & -.06 & -1.07 & .28 & .06 & .004 \\
Friendship Love & .18 & 3.32 & .001 & .18 & .03 \\
Passionate Love & .42 & 8.31 & .000 & .42 & .17 \\
\hline
\end{tabular}

As shown in Table 2, the results of the regression analysis indicated that social interest predicted significantly participants' game playing love $\left(R^{2}=.05\right)$, altruistic love $\left(R^{2}=.09\right)$, friendship love $\left(R^{2}=.03\right)$ and passionate love $\left(R^{2}=.17\right)$.

\section{Discussion}

In this research, the relationship between problem solving in romantic relationships, social interest and love styles was examined. According to the findings of this research, there is a positive relationship between "Physical Abuse" and the type "game-playing love". An early study has showed significant positive relationship between game playing love, possessive love and destructive conflict (Goodboy, Myers \& Members of Investigating Communication, 2010). Individuals with the attitude of love like game are self-centered players who play with love like a game. In this love style, individual is selfish, does not want to develop a commitment to his/her partner and cheating is a rule of this game. Those people may not feel the necessity of functional problem solving in a relationship since they do not want to commit to anyone, they want to be with many people and they want many partners (Hovardaoğlu \& Büyükşahin, 2004).

There was found a negative relationship between "Physical Abuse" and "Passionate Love" style. According to findings of an early study, there is a negative relationship between passionate love and destructive conflict (Goodboy, Myers \& Members of Investigating Communication, 2010). People with Passionate Love style are selfconfident and they can securely attach in a relationship. Passionate lovers are not obsessed or jealous; they just want to have a special relationship. People who adopted this love style can be thought as they might apply more functional ways for problem solving; therefore they might not apply physical abuse.

There was found a positive relationship between "Emotional Abuse" and "Game-playing love". Emotional Abuse can be defined as behaviors of humiliation, swearing, leaving alone, frightening, threatening, disregard, mocking, extreme pressure and establishing an authority (Kalkan, 2008). People with game-playing love style, who are selfish, do not commit and have many partners, can be considered to apply for emotional abuse in dealing with problems. 
There is a negative relationship between "Emotional Abuse" and "Altruistic Love", "Friendship Love" and "Passionate Love". Persons with Altruistic Love their partners despite the flaws, they are forgiving and supportive, and think of their partners more than themselves. Friendship Love style is a love style that depends on protecting each other, and sharing their interests. Passionate Love style is a love style that things such as physical attractiveness, compassion, open to communicate, feeling safe in a relationships and having secure attachment in relationships are in the foreground. These kinds of lovers always try to find a new way to satisfy their partners. The common feature of this love style is being compassionate, caring their partners and wanting their partner's goodness. Therefore, people who adopt Altruistic Love, Friendship Love and Passionate Love are possible not to apply emotional abuse while dealing with problems. Early study has showed significant relationship between love styles, relationship satisfaction (Mishra \& Sharma, 2015) and positive attitudes towards marriage (Y1ldırım, 2020). In another study, positive problem solving was found related to positive relationship outcomes (Gesell et al., 2020).

There was found a positive relationship between "Functional Problem Solving" and "Altruistic Love", "Friendship Love" and "Passionate Love". Previous research has shown that passionate and selfless love styles are positively related to functional dyadic coping behaviors (Vedes et al., 2016). Problem Solving is defined as partners' trying to understand each other in dealing with problems, express their feelings, behaviors that tend to each other's needs, emotions and opinions (Kalkan, 2008). As it was stated above, people who adopt those three love styles consider partners' needs and care their partners. Therefore, it might be thought that while dealing with problems, they tend to functional problem solving which includes understanding partners and caring emotions and opinions.

There was found a negative relationship between "Functional Problem Solving" and "Game-playing love". While functional problem solving is defined as trying to understand partner, tend to others' emotions and opinions; in the style of game-playing love, the person is selfish and wants to have many partners. Finding positive relationship between Game-playing love and Physical Abuse and Emotional Abuse is such as to support the negative relationship with Problem solving.

There was found a positive relationship between "Social Interest" and "Altruistic Love", "Friendship Love" and "Passionate Love" styles. And the results of the analysis indicated that social interest predicted altruistic love, friendship love and passionate love. Social Interest includes increasing friendly collaboration capacity and decreasing hostility (Crandall \& Harris, 1991). People with high social interest know about difficulties in life and how to overcome those (Adler, 1998). Those people are ready to collaborate (Adler, 2002). Since Altruistic Love, Friendship Love and Passionate Love styles include showing interest to partners, sensitivity to partners' needs and compassion love; it can be thought that people who adopt these love styles have high Social Interest. In Özaydınlık (2014)'s study, positive relationship was found between social interest and marital adjustment.

There was found a negative relationship between social interest and game-playing love style. And the results of analysis indicated that social interest predicted game playing love. Game-playing love includes features like selfcentered that people with high social interest do not have. Therefore, people who adopt game-playing love style can be expected to have low social interest. In early study, there was negatively significant relationship between social interest in romantic relationships and hostile sexism (Uysal Çelik, 2018).

The following proposal can be done basing on the obtained results of this research; Physical Abuse and Emotional Abuse are risks for adolescent romantic relationships. For this reason, there is needed preventive and protective studies to prevent and removal of the abuse in adolescent romantic relationships. Social interest helps individuals to solve problems in their romantic relationships since it includes empathy and collaboration. Social interest level of individuals can be tried to increase by giving more place to social and developmental studies in education system. Studies on physical abuse and emotional abuse have mostly been conducted on children and married couples in our country. It will reveal the violence experienced in romantic relationships research is needed. There are very few studies on the concept of social interest in our country. This research can give an idea for new studies to be conducted. 


\section{References}

Adler, A. (1998). Social interest. Colin Brett, USA: Oneworld Publications. Oxford.

Adler, A. (2002). Psikolojik aktivite (üstünlük duygusu ve toplumsal aktivite) (Çev. Belkıs Çorakçı). İstanbul: Say Yayınları.

Alantar, M. (1989). Psychological maltreatment; on attempt its definition by experts and its assessment among a group of adolescents (Master's thesis). Retrieved from CoHE Thesis Center (Thesis No: 7951).

Armstrong, H. L. (2021). Encyclopedia of sex and sexuality understanding biology, psychology, and culture. California: Greenwood.

Aydın, O., \& İşmen, E. (1996). Duygusal istismarın liseli ergenlerin kendini kabul seviyelerine etkisi. Marmara Üniversitesi Atatürk Eğitim Fakültesi Eğitim Bilimleri Dergisi, 8(8), 127-134. https://dergipark.org.tr/tr/pub/maruaebd/issue/363/2042

Azizioğlu, M. (2009). Lise ergenlerinde duygusal istismarın başarlya etkisi (Master's thesis). Retrieved from CoHE Thesis Center (Thesis No: 227457).

Bubenzer, D., Zarski, J., \& Walter, D. (1991). Measuring social interest: A validation study. Individual Psychology: Journal of Adlerian Theory, Research \& Practice, 47(1), 124-135. https://psycnet.apa.org/record/1991-23174-001

Büyüköztürk, Ş. (2006). Sosyal bilimler için veri analizi el kitabı. Ankara: Pegem Yayınları.

Büyükşahin, A., \& Hovardaoğlu, S. (2004). Çiftlerin aşka ilişkin tutumlarının Lee'nin aşk biçimleri kapsamında incelenmesi. Türk Psikoloji Dergisi, 19(54), 59-75. https://kutuphane.dogus.edu.tr/mvt/pdf.php

Crandall, J. E. (1991). A scale for social interest. Individual Psychology: Journal of Adlerian Theory, Research \& Practice, 47(1), 106-114. https://psycnet.apa.org/record/1991-23179-001

Crandall, J. E., \& Harris, M. D. (1991). Social interest, cooperation, and altruism. Individual Psychology: Journal of Adlerian Theory, Research \& Practice, 47(1), 115-119. https://psycnet.apa.org/record/1991-24198001

Creasey, G., Kershaw, K., \& Boston, A. (1999). Conflict management with friends and romantic partners: the role of attachment and negative mood regulation expectancies. Journal of Youth and Adolescence, 28, 523543. https://link.springer.com/content/pdf/10.1023/A:1021650525419.pdf

Evii, M. (2020). Adlerian social interest, anorexia nervosa, and cognitive reconstruction. Journal of Individual Psychology, 76(3), 273-285. DOI: 10.1353/jip.2020.0029

Feiring, C. (1996). Concepts of romance in 15-year-old adolescents. Journal of Research on Adolescence, 6(2), 181-200. https://psycnet.apa.org/record/1996-03765-003

Fung, T. Y., \& Webster, R. (2018). Perceived social support, social interest, and mental health: Testing a mediator model. Journal of Individual Psychology, 74(2), 157-171. DOI: 10.1353/jip.2018.0010

Gesell, N., Niklas, F., Schmiedeler, S., \& Segerer, R. (2020). Mindfulness and romantic relationship outcomes: the mediating role of conflict resolution styles and closeness. Mindfulness, 11, 2314-2324. https://doi.org/10.1007/s12671-020-01449-9

Goodboy, A. K., Myers, S. A., \& Members of Investigating Communication (2010). Relational quality indicators and love styles as predictors of negative relational maintenance behaviors in romantic relationships. Communication Reports, 23(2), 65-78. DOI: 10.1080/08934215.2010.511397

Hendrick, C., \& Hendrick, S. (1986). A theory and method of love. Journal of Personality and Social Psychology, 50 (2), 392-402. https://doi.org/10.1037/0022-3514.50.2.392 
Huo, D. (2019). Social interest and collectivism: A study in Mainland China. (Doctoral dissertation, The Faculty of Adler University). Retrieved from https://search.proquest.com/docview/2447534202?pqorigsite $=$ gscholar $\&$ fromopenview $=$ true

Jaremka, L. M., Kane, H. S., Sunami, N., Lebed, O., \& Austin, K.A. (2020). Romantic relationship distress, gender, socioeconomic status, and inflammation: A preregistered report. Personal Relationship, 27, 708727. https://doi.org/10.1111/pere.12338

Kalkan, M. (2008). Ergenler için romantik ilişkilerde sorun çözme ölçeğinin geliştirilmesi, geçerlik ve güvenilirliği. Çocuk ve Gençlik Ruh Sağlı̆̆l Dergisi, 15(3), 131-138. http://cms.galenos.com.tr/Uploads/Article_30244/cogepderg-15-131.pdf

Kalkan, M., \& Ersanll, E. (2008). The effects of the marriage enrichment program based on the cognitivebehavioral approach on the marital adjustment of couples. Educational Sciences: Theory \& Practices, 8(3), 977-986. https://files.eric.ed.gov/fulltext/EJ837773.pdf

Kalkan, M. (2009). Adlerian social interest scale-romantic relationship form: scale development and psychometric properties. Individual Differences Research, 7(1), 40-48. http://dx.doi.org/10.13072/midss.311

Kansky, J., \& Allen, J.P. (2018). Long-term risks and possible benefits associated with late adolescent romantic relationship quality. Journal of Youth and Adolescence, 47(7), 1531-1544. DOI: 10.1007/s10964-018$\underline{0813-\mathrm{X}}$

Leak, G., \& Leak, L. (2006). Adlerian social interest and positive psychology: A conceptual and empirical integration. Journal of Individual Psychology, 62(3), 207-223. https://utpress.utexas.edu/journals/06-fall$62-3$

Leak, G. K., \& Gardner, L. E. (1990). Sexual attitudes, love attitudes, and social interest. Individual Psychology: Journal of Adlerian Theory, Research \& Practice, 46(1), 55-60. https://psycnet.apa.org/record/199025183-001

Leak, G., Millard, R., Perry, N., \& Williams, D. (1985). An investigation of the nomological network of social interest. Journal of Research in Personality, 19(2), 197-207. https://doi.org/10.1016/0092$\underline{6566(85) 90028-5}$

Mishra, S., \& Sharma, D. (2015). Do love styles predict relationship satisfaction? The Journal of Positive Psychology, 4, 73-83.

Özaydınlık, Ş. (2014). Evli çiftlerin evlilik uyumu ile kişilik özellikleri ve romantik ilişkilerindeki sosyal ilginin incelenmesi (Master's thesis). Retrieved from CoHE Thesis Center (Thesis No: 372315)

Rennebohm, S. B., Seebeck, J., \& Thoburn, J. W. (2017). Attachment, dyadic adjustment, and social interest: An indirect effects model. The Journal of Individual Psychology, 73(3), 208224. https://doi.org/10.1353/jip.2017.0017

Sarı, T. (2008). Üniversite öğrencilerinde romantik ilişkilerle ilgili akılcı olmayan inançlar, bağlanma boyutları ve ilişki doyumu arasındaki ilişkiler (Doctoral dissertation). Retrieved from CoHE Thesis Center (Thesis No: 257552)

Shulman, S., \& Scharf, M. (2000). Adolescent romantic behaviors and perceptions: age-and gender- related differences and links with family and peer relationships. Journal of Research on Adolescence, 10(1), 99118. DOI: $10.1207 /$ SJRA1001_5

Tosuntaş-Karakuş, F. (2006). Ergenlerde algllanan duygusal istismar ile sosyal beceri arasındaki ilişki (Master's thesis). Retrieved from CoHE Thesis Center (Thesis No: 191634). 
Uysal Çelik, Z. (2018). Üniversite öğrencilerinin romantik ilişkilerde sosyal ilgi düzeyleri ile çelişik duygulu cinsiyetçilik düzeyleri arasındaki ilişki (Master's thesis). Retrieved from CoHE Thesis Center (Thesis No: 517236).

Vedes, A., Hilpert, P., Nussbeck, F. W., Randall, A. K., Bodenmann, G., \& Lind, W. R. (2016). Love styles, coping, and relationship satisfaction: A dyadic approach. Personal Relationships, 23(1), 84-97. DOI: $10.1111 /$ pere. 12112

Yalçın, S. (2007). Ergenlerde algllanan duygusal istismarın uyum düzeyine etkisi (Master's thesis). Retrieved from CoHE Thesis Center (Thesis No: 217689).

Yıldırım, E. (2020). Üniversite öğrencilerinin aşk stilleri ile evlilik tutumları arasındaki ilişkinin incelenmesi (Master's thesis). Retrieved from CoHE Thesis Center (Thesis No: 653163).

Watkins, E. (1994). Measuring social interest. Individual Psychology: Journal of Adlerian Theory, Research \& Practice, 50 (1), 69-96. https://psycnet.apa.org/record/1994-43557-001 